\title{
INTRODUCTION
}

\section{On War and Accountability}

\section{Alisse Waterston}

\begin{abstract}
This article centers on a set of discussions around 'accountability' as it pertains to war: accounts of war, accounting for war, what war accounts for, and accountability, including anthropological accountability. The essay details stories that ethnographers tell about what they have seen, heard, and done on the front lines. It reviews explanations for the causes, patterns, and practices of war, and for the occurrences of specific wars. The discussion also highlights what war explains, that is, how war creates its own outcomes. It considers who is to be held responsible for all the death and destruction that war inevitably brings and discusses impunity as systemic and strategic. Also considered is the responsibility of anthropology and anthropologists in facing up to the most significant crises of our times.
\end{abstract}

Keywords: accountability, anthropology, capitalism, imperialism, impunity, power, violence, war

My worry is that anthropology may have become too self-marginalized as a discipline, increasingly irrelevant to the big questions of the day in our world, content to snipe from the sidelines as soon as it seems safe ... It would be nice if anthropologists could be among those leading this discussion, rather than merely following it at a safe distance. (Nolan 2006)

This book on anthropology and war is a direct product of ... a crisis of conscience which has called into question the right of anthropologists to remain aloof from the great issues of our times. (Fried, Harris, and Murphy 1967)

... seeing is power. (Nordstrom 2007)

The 1967 volume, War, edited by Morton Fried, Marvin Harris, and Robert Murphy, grew out of an "unprecedented plenary symposium" of the 66th annual meeting of the American Anthropological Association. The symposium was 
held, according to the authors, because one year earlier, 350 anthropologists attending the association's annual meeting had signed a petition declaring their "widely shared sentiment that anthropologists have both a moral and professional concern for the effects of war on the human species." The petition called for organized symposia to take place the next year that would counter the fact that only a "miniscule portion of the [1966] meeting's formal papers and symposia had displayed any concern for the critical issues of contemporary society" (Fried, Harris, and Murphy 1967: x).

Oh, how the times they have changed, and, oh, how they have not. The prospect for peace with justice looks bleak as we move deeper into the twenty-first century. The horrors of modern warfare-the deaths, mutilated bodies, dehumanization, destruction of social and material infrastructures-have not shocked the world enough to bring about an end to war. Instead, the arrogance of power marches on. In violence and with confidence, it creates and maintains conditions of scarcity while protecting private, concentrated wealth. "[W]ar is not sporadic anymore, it is permanent," claims sociologist Jean Ziegler. "It is not any more a crisis ... but normality" (Accardo 2005). In this time of permanent war, the US imperialist project takes center stage, the arrogance of its structural power marching on in active, interventionist warfare in Iraq and Afghanistan, and certainly more covertly elsewhere. Of course, this is not a brand-new development. Since the twentieth century, US power and wealth have greatly expanded, as Lesley Gill (2007: 142) puts it, "by killing, manipulating, and impoverishing the peoples who anthropologists traditionally study” (see also Dewey 1927).

Debates remain in US anthropology about whether the discipline, individual anthropologists, and the largest association of anthropologists in the world should remain "aloof from" or actively engage in the "great issues of our times" (Fried, Harris, and Murphy 1967: ix). Yet since 1967-over 40 years ago-more and more anthropologists have stopped believing that neutrality and objectivity are the values to which we ought to subscribe. Instead, they put a premium on ethics, responsibility, philosophical pacifism, and anti-war and anti-imperialist political activism (Gjessing 1968; Gough 1968; Hastrup et al. 1990; Holland et al. 2007; Jones 1971; Ortega 2006; Price 2004; Rylko-Bauer 2008; Rylko-Bauer, Singer, and Van Willigen 2006; Sanford and Angel-Ajani 2006; Singer 1990; Wolf and Jorgensen 1970). There are now many anthropologists who no longer believe in fairy tales, who do believe that "to say nothing is as much a significant act as to say something" (Berreman 1968: 392), and whose work and anti-imperialist engagements have been radical, revolutionary, and effective, even if not entirely transformative. For example, at recent annual meetings of the American Anthropological Association (AAA), anthropologists passed three important resolutions, in part motivated by the Pentagon's attempts to recruit anthropologists into US military initiatives: one resolution condemns and calls for an end to the US occupation in Iraq (AAA 2006); a second condemns torture and demands full US compliance with the UN Convention against Torture (AAA 2006); and a third opposes US military actions against Iran (AAA 2007).

As with the 1967 volume, this special issue of Social Analysis, titled "An Anthropology of War: Views from War Zones," grows out of an important event at the 
2006 AAA annual meeting - a presidential panel that drew an audience of approximately 500 anthropologists. For this collection, I asked the contributors, all of whom have been working in war zones, to make a clear and powerful statement concerning what they know about war: its precursors, its causes, its aftermaths, its effects on human lives and on the future of humankind. Each contributor has been a witness to war and can draw on examples of conflicts from various sites around the world. They tell stories, from their vantage point, of what they have seen, heard, smelled, read about, studied, analyzed, remembered-what they think and feel about war. They share with readers the big take-away messages from their years of research, activism, and experience in war zones. The reach of US imperial ambition is strikingly apparent as the authors transport us from Colombia and Guatemala to Israel and Palestine, Iraq, Afghanistan, Haiti, and elsewhere-sites of direct and indirect US military intervention and occupation, political influence and authority, and imperialistic economic undertakings and policies.

\section{Reckonings}

It has been a humbling experience for me to work on this special issue and this introduction. I am awed by the contributors, what they know and their intense experiences in war zones. I am also struck by the sheer quantity of literature on war by historians, philosophers, social critics, journalists, novelists, and anthropologists. It is overwhelming, as Brian Ferguson notes in "Ten Points on War," his article in this collection. Referring just to the literature in anthropology, Ferguson recalls the days when it was "possible to read practically everything that came out on the subject." There is no longer a way to offer a comprehensive work on the anthropology of war, and it is not the intention of this publication to do so. Instead, this collection takes up Carolyn Nordstrom's challenge: if we were to look back on the current moment from 100 years into the future, what would have been important to know about war?

Let me be blunt about the ambition here. My goal in putting together this collection is to undermine war, to help bring an end to war and the US imperial project. There are thousands of US anthropologists who, in Nordstrom's words, "have been producing academic scholarship while at war," whether or not war is the focus of their work. The whole world is living in a time of war-not just particular wars but continuous, imperial war, which has a tremendous, if differential impact, on the lives of most people everywhere across the globe.

I come to this collection not as an expert on war but as a person living in a time of war who grew up in a century marked by war, has brought children into this war-torn world, and tries to teach young people about it. This collection is not just an intellectual exercise but a plea-desperate, frantic, anxious. Maybe this slight volume, this special edition of an academic journal, can find its way into the hands of the public and into global consciousness, so that we might find a way to end this insanity and be safe.

"How in your opinion are we to prevent war?-still unanswered ... let us make the attempt; even if it is doomed to failure," Virginia Woolf proposed 
([1938] 1966). For us, it may be too late for prevention, but we can ask instead, "How in your opinion are we to bring an end to war? - still unanswered." In order to end war, we need to understand it. Even if our efforts are doomed to failure, with this collection we attempt this essential step.

In "Prelude: An Accountability, Written in the Year 2108," Nordstrom offers an insight that is also a charge: "The way we explain our todays creates our tomorrows." Inspired by this challenge, I present in this introduction a set of discussions on accountability as it pertains to war. First, there are the anthropological accounts, the stories that ethnographers tell about what they have seen, heard, and done on the front lines. The contributors to this volume are among the leading ethnographers of war, braving the field to bring back raw truths. Then there is the accounting for war, explanations that help us understand causes, patterns, and practices of war, as well as occurrences of specific wars. Embedded in these explanations is another aspect of accountability: who is to be held responsible for war and where in our current arrangements does impunity tend to lie? War, as Ferguson so wisely notes, is not just something to be explained; war accounts for what we see on the ground, in any aspect of social life. These facets-accounting for war and what war accounts for-are inseparable. That war both explains and needs explaining reflects the dialectic of war. Then there is the responsibility of the discipline and ourselves as anthropologists with regard to the great issues of our times. I close the introduction to this volume with a reflection on anthropological accountability.

\section{Accounts: Stories from the Front Lines of War}

In her "different kind of war story," Nordstrom (1997: 16-17) makes the sharp observation that "most writing about violence in western theory never deals with actual violence ... in most of these cases people are writing from the safety of a nonviolent situation.” Except maybe anthropologists who, like Nordstrom, can theorize the violence of war while keeping hold of the " "wild cr[ies]' of terror, passion, mystery, rage ... despair” (ibid.: 17-18) that real people in real wars experience. The ethnographic project brings anthropologists to the places where bullets are fired, where flesh is torn, where blood, brutality, and death are intertwined.

We need to go to that place and sit with it, learn from it. It is raw and tangible, the content that must be absorbed before we can go to the abstract. “Dead bodies and ruined houses," Woolf tells us, "are not an argument ... [but] a crude statement of fact" ([1938] 1966: 11). Dead bodies and ruined houses are war for ordinary folk, the civilian and combat soldier. We do need to understand the ways in which war is the clash of classes, armies, and empires played out on structurally uneven killing fields. We must also see that war is hell, a truth made cliché by fatigue, indifference, misrepresentation, and abstraction.

Poetry and fiction can bring us there, from Johnny Got His Gun (Trumbo [1939] 1989) to Slaughterhouse-Five (Vonnegut [1969] 1991) and All Quiet on the Western Front (Remarque [1929] 1982), the novel that first awakened me to war. "But all limped on, blood-shod. All went lame; all blind," wrote Wilfred Owen, the prolific 
poet-soldier killed in World War I at age 25 (Fussell [1975] 2000: 288). From Siegfried Sassoon, Owen's friend and fellow poet, came "The Hero" (ibid.: 7):

Blown to small bits. And no one seemed to care

Except that lonely woman with white hair

At the level of journalism, ripped bodies so often hide the truth. Ethnography offers a bridge from journalism to theory to reveal that which has been hidden. It is a method that helps us see our own cultural assumptions and definitions, and that forces us to test our abstractions against the experiential. From it we get stories that we then link to other stories, a people's history of war. "[T]he bomb," Nordstrom explains in "Global Fractures" in this volume, "is a locatable event and a personal experience. But it is not singular. It is (quite literally) simultaneously embedded in the person hit, the larger networks of interplay among people and events, the war itself, and the global values and structures that sustain these realities." This linking of context and content is the great promise of anthropology.

The accounts in this volume aim to fulfill that promise. In "Military Occupation as Carceral Society," Avram Bornstein shocks us with the slap in the face he got from an Israeli soldier at the military checkpoint marking the Green Line between the West Bank and Israel. Bornstein brings us the sorrow, confusion, and rage of a Palestinian family battered by the rituals of occupation: surprise home-invasion night raids, violent interrogation, imprisonment, mothers facing choice-less choices. These stories draw us into the systems and structures that are built into occupation, not least of which is the architecture of control: prisons, checkpoints, walls. These systems and structures are implicated in the violence (see Bornstein 2002). The human toll and social consequences are felt by all parties involved. The violence escalates, no one is left unscathed, and nobody is secure.

Jose Vasquez brings us to war from several vantage points. An anthropologist, Vasquez's experience in war zones comes from his duties as a member of the United States Armed Forces, which led to his becoming an activist in Iraq Veterans Against the War. ${ }^{1}$ In "Seeing Green," Vasquez focuses on perspective. We view the war through the lens of the latest high-tech equipment, devices that distort our perception of what is actually on the ground. Is it the enemy? An innocent? A human being? The theater of war has been transformed into a personal media center where war is always on, day or night, and distance becomes an enabling factor. Players, now armed with night vision goggles, laser range finders, and thermal sights, engage in video game-like competition in which 'targets' are dehumanized entities. In the lens with a view, objects that come into focus are cast in an eerie green glow, more monster-like than human. Thus, distant in space and removed from humanity, the objects get blown up by weapons unleashed by soldier-players on the ground and in the air. What is left, Vasquez says, are "little green men (or children or women) exploding on their screens." Modern warfare makes the Rashomon effect more likely to occur, and less likely that anybody will be held accountable for mistakes. No one feels 
remorse, a haunting thought considering that 90 percent of all war casualties these days are civilians (Nordstrom 1997: 5; Tickner 2001: 49).

Lesley Gill, Beatriz Manz, and Carolyn Nordstrom are dedicated chroniclers of war-torn societies. Working in the field for several decades, Gill has brought us to a struggling immigrant community in Bolivia (Gill 2000) and the chilling classrooms of the School of the Americas (Gill 2004), and now brings us to Colombia, the focus of her article in this collection. Colombia is not merely a sovereign nation-state entrenched in a 40-year civil war, but also a good case study of a US-shaped Cold War/post-Cold War counterinsurgency war in which "a range of new militaries - the decaying remnants of state armies, paramilitary groups (often financed by governments), self-defence units, mercenaries and international troops-engage in new forms of violence [including] ... systematic murder" (Shaw 2000: 172). In "War and Peace in Colombia," Gill tells the story of Barrancabermeja, a city located in a hot region of the state's counterinsurgency war and an important oil refinery center fueled by corporate neo-liberalism. Do not be fooled by any appearance of calm in Barrancabermeja, Gill and her informants warn. This place, like many others across the globe, exists at the "ragged edges of war and peace." Statistics come alive in Barrancabermeja. In times past, 80-90 percent of casualties in all wars were military, not civilian (Shaw 2000: 172). This was when war had clear-cut front lines and clear distinctions between warriors and civilians, as Gill points out. Over the years, Barranqueños have disappeared, have been massacred, kidnapped, and assassinated-civilian casualties in a war of terror funded by a vast amount of US military aid.

There is no peace with justice in Barrancabermeja. A criminal shadow state has emerged, monopolizing all sectors of material and social life and pressing more Barranqueños into poverty. Feeling vulnerable and nervous, they have become silent. Beatriz Manz is quite familiar with this scenario. She knows of what Gill speaks in describing Barrancabermeja's "tattered social fabric." Manz has been studying the aftereffects of counterinsurgency war for about 35 years, focusing on the rural Mayan communities of Guatemala and their refugees, who have been displaced by a war aided and abetted by the United States (Manz 1988, 2004). "The fabric of society ... was shredded during the ferocious internal armed conflict. The legacy of state terror is everywhere," Manz informs us in "The Continuum of Violence in Post-War Guatemala," her article in this collection. Over 10 years ago, peace was 'achieved' in Guatemala. But there is no peace, Manz tells us, and she explains why. In Guatemala, poverty is rampant, militarization of daily life is the standard, power gets away with murder, vigilante justice is customary, and people are traumatized, afraid, intimidated, frustrated, and in despair. Murder is on the rise, as is violence against women, and all of this is the aftermath of counterinsurgency war. Although we can root contemporary social dysfunctions in war, this explanation of the present situation in Guatemala is downplayed or ignored. Instead, today's atrocities are described as acts of common criminality perpetrated by individuals and gangs, the latter often fomented in Guatemalan prisons. To stem the violence and counter the legacies of terror would require both a redistribution of resources 
and an embrace of inclusiveness, fairness principles that are absent from the policies and practices of neo-liberal capitalism and cosmopolitan politics-the key obstacles to peace with justice.

Nordstrom does not report directly from Guatemala or Colombia, but her analysis in "Global Fractures" fits with those places. Nordstrom bases her understanding of the contemporary world on decades of research she has conducted in war zones from Sri Lanka to Mozambique. Her research has led to some of the most important writing on our war-torn world available, including the brilliant A Different Kind of War Story (1997) and the illuminating Global Outlaws, an ethnography of "invisible (illegal) realities and placeless hyper-placed global flows" (2007: xi). Nordstrom is the consummate storyteller who, with grace and integrity, introduces us to the brave, the resourceful, the resilient, the opportunistic, the creative, the mercenary, the peace-loving, and the violent. "We are glad you finally came to ask us our story; up until now, everyone has come to tell us what our story is,'” Nordstrom (1997: 79) quotes her Mozambican informants. There is a yearning to emerge from the forced silence no matter the danger. Nordstrom reports in "Global Fractures" that her informant was "so outraged that he was willing to risk telling his stories to an anthropologist." The anthropological account is his story, told so that the rest of us can begin to understand, to see. Too many of us can see, but do not see (Saramago 1998: 292). Silencing and blinding are political projects, weapons of the dominant. Speaking and writing are tools of resistance. Seeing is a power that might help us off our current, destructive course.

Nordstrom makes us see. Politically sophisticated and ethnographically rooted, "Global Fractures" is a theoretical and philosophical commentary that inspires and stirs. The world is in crisis, which is understood as more than a singular event situated in one place or at one moment in time. Instead, it encompasses "Badiou's multiple multiplicities"-many events and situations bumping into each other, crashing, pushing others out of the way, others crashing into still others, going backwards, sideways, forwards-"extend[ing] across the borders of sovereignty and temporality to flow into the personal lives, economic markets, and political systems ... across war and peace."

This world of crisis within which we are all living is very fragile. The fracture lines can break very easily. It does not take much. We cannot make them out very easily and need a special lens to discern margins, boundaries, and breaks, and how they are inter-connected, inter-twined, inter-dependent. Nordstrom provides that lens, allowing us to trace the fracture lines, to find and follow the trails. The trails are hard to see until we get the focus. Then we notice their footprint and find that they are rather well-established and becoming institutionalized. We see how they work (the togetherness of legal/extra-legal, state institutions/extra-legal) and why (profiteering for profiteers), and where they may be taking us (the human fallout, more crises, more ironies and specific downfalls). With these concepts and descriptors, in "Global Fractures" Nordstrom provides a broad framework within which we can better understand the state of the world, its fragility, its unsustainability. Since no one is invulnerable to the quakes along the fracture lines, the future looks at once grim and hopeful. 
In "Global Warring Today," war scholar Stephen Reyna also takes up the idea of crisis, offering the "global warring hypothesis" to propose analytic distinctions between local, global, and world warring. He situates US military violence in the context of capitalist and imperial politics, an explanatory framework that illuminates each of the cases that follow in this collection. Reyna's global warring hypothesis is also prognostic and prophetic. It allows us to anticipate future actions by a dominion thus defined: "For an empire, the conjunction of severe systemic crisis co-occurring with severe competition means that there is little that can be done in its economic sphere to resolve this predicament, prompting recourse to the political sphere and violence. If the scale of this crisis is worldwide, then intense global warring is predicted." The United States, on an imperial mission while at the same time struggling to stay on top in fierce global economic competition, is losing power. This thesis, which has been proposed by scholars and the CIA, more recently has become a topic of discussion in the popular media (see, e.g., Khanna 2008). Operating on the fracture lines, the US reveals its vulnerability by stoking the violence in Afghanistan, Iraq, Lebanon, Chad, Sudan, and Colombia, sites of global warring examined by Reyna. Yet the empire rests on enormous military real estate. According to the latest government records, the Department of Defense is "one of the world's largest 'landlords' ... located on more than 5,300 sites [823 overseas, 4,488 in the US and territories], on over 32 million acres" (DOD 2007: 2). Do these figures reflect enormous strength, or is the escalating violence a sign of weakness, as Hannah Arendt might suggest? "Rule by sheer violence comes into play where power is being lost," Arendt wrote nearly 40 years ago. "To substitute violence for power can bring victory, but its price is very high; for it is not only paid by the vanquished, it is paid by the victor in his own power" (Arendt 1969). Reyna makes us wonder if today's "imperial global warriors" will take us all down with them.

In his essay for this volume, physician-anthropologist Paul Farmer notes the "gruesome symmetry" in two US imperial disasters: Iraq and Haiti, each of which is a "proverb for brutality." An anthropologist by perspective and a healer by practice, Farmer not only analyzes the real costs of war but also fixes the bodies that get torn apart by it. In "Mother Courage and the Future of War," Farmer lays bare for us the structural conditions that lead poor youth of color to enlist in the US 'Army of One', such as Joe, Farmer's young Haitian friend and son to Yolande, a courageous mother who stood up to her US captors and won, although her son still battles in Fallujah. Farmer draws for us the contradictions and the intimate links between the US and the countries it wounds, the people who endure suffering, and the shame and grief of it all-the terrible price of war and empire.

R. Brian Ferguson is a war scholar and anthropologist with an extensive portfolio of writings on the topic. Ferguson's work, which takes the long view, is interdisciplinary in method and comprehensive in scope. He examines archaeological records; reads newspapers; looks to history; probes political science, economics, and philosophy; examines biology and psychology; and, of course, reads almost everything on the anthropology of war. For this volume, 
Ferguson gives us "Ten Points on War," a refreshingly clear and direct summary of what is important to know if we want to understand war. In what follows, I use aspects of Ferguson's paradigm to explain war, a discussion to which each of the authors in this volume contributes.

\section{Accounting for War}

"Why fight?" Virginia Woolf asks ([1938] 1966: 6). Almost ritualistically, at least in Western thought and conversation, the first response usually goes something like this: "We fight because it is in our nature, human and social. War is inevitable, an inherent part of mankind's instinctual being. It is pre-programmed, coded in our genes. It is just there, always there, ready to explode, anytime and anywhere." This explanation for war got a boost from Thomas Hobbes (1964), whose seventeenth-century treatise on the horrors of human nature fit the prevailing political economy of his time (the English Civil War, British empire building), serving then as it does now to justify the coercive power of the state. Whether we are conscious of it or not, we have been taught to believe that what is needed is a strong, governing authority without which the worst of our instincts will emerge, rendering our lives, as the slogan says, "solitary, poore, nasty, brutish, and short" (ibid.: 85). It is worth repeating Hobbes's view, written in 1651 (ibid: 84):

So that in the nature of man, we find three principall causes of quarrel. First, competition; Secondly, Diffidence; Thirdly, Glory. The first, maketh men invade for Gain; the second, for Safety; and the third, for Reputation. The first use Violence, to make themselves Masters of other mens persons, wives, children, and cattell; the second, to defend them; the third, for trifles, as a word, a smile, a different opinion, and any other signe of undervalue, either direct in their Persons, or by reflexion in their Kindred, their Friends, their Nation, their Profession, or their Name. Hereby it is manifest, that during the time men live without a common Power to keep them all in awe, they are in that condition which is called Warre.

Although it has been refuted time and again, the 'war in nature' argument is deeply embedded in popular thinking, revived and kept alive by deeply flawed and less than meticulous scholarship, as Ferguson makes clear in the first point of his "Ten Points on War." The argument is still sexy and gets attention in popular and academic publications because 'the horrors of human nature' theory fits the prevailing political economy of our times (war, empire).

The 'war in nature' argument has awful consequences. If we buy into the Hobbesian logic, there is no other choice but to have blind faith in sovereign authority, although some forms of authority are superior to others. By this logic, we are better off with fascism than no authority at all. The argument ends discussion of alternative solutions to the waging of war. We are powerless in the face of our destiny and must, for the sake of humankind, submit in humble obedience to a supreme state. 
Also, the 'war in nature' argument inhibits us from considering alternative explanations for war. It is the discussion stopper I have all too often experienced in conversations about war with family and acquaintances. However, given the chance to consider alternatives, most people, I venture, would welcome them, yearning as they likely are for truth and hope. "Had you not believed that human nature, the reasons, the emotions of the ordinary man and woman, lead to war, you would not have [asked]," Virginia Woolf remarks to her imaginary interlocutor in answer to his question about "how to prevent war" ([1938] 1966: 6). Woolf reveals here humankind's desire for explanation, a longing for answers despite all illogic: why would the interlocutor, a man of means and power, pose this profound question to a woman with neither means nor power (ibid.: 12)?

The great thinkers and moralists are not satisfied with tired, wrong-headed myths. Myths are easy: they provide a pat narrative; they are easy to remember, uncomplicated, and mutually recognizable; they demand nothing of us but obedience or repetition. Reality is just the opposite: the narrative is not linear but interweaving and complex; it is difficult to keep track of all the variables involved; it is complicated and entails disagreements and contradictions; it requires us to think deeply and critically. Reality demands from us passion, action, and partiality. The contributors to this volume are among the great thinkers and moralists of our time. Each offers part of the answer, a piece of the explanation, and aspects of theory that bring us to a fuller, deeper understanding of why we fight. They put forth arguments that collectively account for dead bodies and shattered homes.

In accounting for war, there are two interdependent orders of explanation. One has to do with description, the other with causality. Descriptive explanation reveals general characteristics of war. Intrinsic to those characteristics are the complex of reasons for particular occurrences of war. The descriptions offered in our collection reveal that modern warfare involves extraordinarily sophisticated tools and weaponry that let loose occasions for war across ever-widening spaces, crossing sovereign states and geo-political borders, blurring the boundaries between war and peace (see also Kapferer 2004). The technology may be flawed and not yet entirely perfected, but its capability is there, bringing with it the logic of ever more war. The weapons of the powerful include the built environment: prisons, walls, and checkpoints comprise the machinery of oppression wherever there is war and uneasy peace. The weapons of the vulnerable are in motion as well, in a loop system with high-tech war tools. Nothing stands alone. Weapons, information, and provisions are all cosmopolitan products, circulating in a massive network of global proportions. In Ferguson's paradigm (1999: 389-390), these aspects constitute the infrastructure of war, "the broad conjuncture of variables involving interaction with the physical environment, population characteristics and trends, technology, and the labor techniques of applying technology, which affect a people's physical existence and relation to nature." Infrastructure both constrains and enables the possibility of war.

War cannot happen without the participation of those who enact it and the compliance of the masses who stand on one side or the other of the battle line. Participants need to be pressed into service, and consent and complicity need to 
be roused. There is a mobilization process where lines are drawn, potent language is utilized, groups are demonized and dehumanized, justification is put on spectacular display, duty is summoned, virtue invoked, trophies bestowed, and the satisfaction of real or perceived needs is tied to outcomes. There is a repertoire of propaganda upon which to draw-war in the name of God, country, democracy, freedom, security. It is calculating, but, as Ferguson (1999: 390) notes, "the values are true to local culture," values that are inculcated, harnessed, and exploited. This aspect of war Ferguson considers superstructural, "the mental constructs of culture, its belief systems, and patterned emotional dispositions" (ibid.).

All this mobilizing and manipulating, harnessing and exploitation are not executed by disembodied entities. While they may be difficult to pin down and identify, people make war-related decisions, even though the spheres of influence are not evenly proportioned among all decision makers (nor uniform in effect or in operation), and even though war-related decisions are shaped by the logic of impersonal, socio-political, and economic structures. Imperial capitalism, for example, does not decide to go to war, but the logics that flow from its organizing principles lead decision makers down that path. Scarcity (of resources, even basic ones) is not necessarily an actual condition, but one that needs to be created and maintained to fulfill a functional requirement for capital accumulation. In each war we read about in these pages, manufactured scarcity (the lack of access to resources or protecting access to them) is fundamentally accountable for the violence, leading to further contradictions. As Reyna explains, capitalism's hyper-dependency on oil, a non-renewable, scarce resource, creates the kind of systemic crisis that brings us to global warring.

Although the ultimate logic may rest in impersonal forces, people with the power to make decisions are the ones who make war. "To understand war," Ferguson explains in this volume, "it is essential to understand the structure of decision making and to identify the total interests-internal and external-of those involved in it." In their articles, Bornstein, Manz, Gill, Reyna, and Nordstrom identify and thread together the set of internal (local) and external (global) interests that in complex interplay result in war, uneasy peace, and the violence they observe on the ground. In Ferguson's paradigm, the structure of war is constituted in the totality of social relationships-how these are organized, patterned, and institutionalized. Since structure comprises "organized social life, patterns of interpersonal connections and divisions sorted into social organization, economics, and politics" (Ferguson 1999: 390), it is at this level that the social dynamics of inequality - the dialectic of social life-can be analyzed. Layered as they are "in a nested hierarchy of progressively more limiting constraints" (Ferguson, this volume), each of the three levels in Ferguson's framework sets the possibilities and limitations for the other levels, forming altogether an accounting for war.

Hobbes was not entirely off the mark. Competition, diffidence, and glory may be identifiable attributes of war, but they are rooted in the logic of particular social dynamics, not in nature. That we can find some general characteristics common to any war does not constitute evidence that war is natural 
or inevitable-only that it is a patterned social phenomenon that under certain social conditions might even be foreseen.

\section{Impunity and Accountability}

Our authors make clear who wins and who loses in war. "Leaders favor war because war favors leaders," Ferguson informs us in "Ten Points on War." Leaders are those representing the interests of the elite who, as Manz explains "enjoy privilege, access to the resources of the society, and the protection of the state apparatus." The killing elite use violence to protect those structures that privilege the few rather than the many. They make violence with weapons of war and of policy, including trade agreements, arms deals, loan contracts, and international finance arrangements. Bombs kill, and so does the denial of the most basic of resources such as water (privatized or dammed up) and food (produced for the market, not use, and the destruction of eco-zones), resources ever more difficult to access in today's global political economy. The death and destruction toll-lives lost, houses ruined, social infrastructures destroyed, bodies maimed, souls lost-are beyond computing.

To come to terms with accountability-who is to be held responsible for all the death and destruction-is terribly difficult. Whose hands are bloody when the logic of a system draws participants into the vortex of violence and war? In his meditation, On War, Howard Zinn (2001: 119) writes of the "infinite chain of causes, that infinite dispersion of responsibility, which can give infinite work to historical scholarship or sociological speculation, and bring an infinitely pleasurable paralysis of the will. What a complex of motives!"

Who is to be held responsible? Is it, for instance, weapons-of-mass-destruction engineer Anh Duong, a Vietnam War refugee employed by the Pentagon, featured in the illuminating documentary Why We Fight, dubbed by colleagues as "the bomb lady," and regarded by them as "one of the most important weapons-developers of the modern era” (Blumenfeld 2007: A3)? Is it the bombardier who, by virtue of video-game-like high technology, can dispel any qualms about the multitudes of human lives he eradicates? Is it the commander who orders bombardiers to drop which bombs where? Is it he who presides over the most powerful military in the world, under whose command tens of thousands have been annihilated? Today that would be George W. Bush, whose regime of violence sacrifices innocents, "killed to achieve the US killing elite's vision of being blackmailer to the world" (Reyna). Or is it those of us who, like Virginia Woolf's British ladies, however unconsciously “desired 'our splendid Empire' ... desired our splendid war" ([1938] 1966: 39) for the benefits we get from these?

In Eichmann in Jerusalem: A Report on the Banality of Evil, Hannah Arendt ([1963] 1992: 247) provides an outline for a method of accountability: "[T]he degree of responsibility increases as we draw further away from the man who uses the fatal instrument with his own hands." Put another way, Farmer suggests that we trace "the social life of dangerous things" (Rylko-Bauer 2007: 3; see also Farmer n.d.) to reveal the nested hierarchy of progressively more 
essential (and thus responsible) cogs in the wheel. Farmer starts with the ethnographically visible, in this case, a little boy who landed on Farmer's surgery table in Rwanda after handling a war weapon that had been placed 12 years earlier during the genocide of 1994. Farmer "pick[ed] out pieces of plastic" from the child's torn body and then sought to identify the fragments. It was a land mine, as Farmer suspected, "manufactured I'm quite sure, not in Rwanda [but] in Europe, the United States, or perhaps Russia," a war weapon that by "sinister design" looks like an innocent plaything (Farmer 2006; see also Farmer n.d.).

In this next account, like all her reports from the field, Nordstrom (1997: 5) follows the footprints, exposing massive inter-linkages across the globe:

I have seen the same weapons vendors, mercenaries, military advisors, supplies, and military training manuals-both illicit and formal-circle the globe, moving from one war to the next. Politicians, military and paramilitary troops and diplomats meet and talk across virtually all boundaries of nation and state. Business salespeople and blackmarketeers sell the items necessary to outfit troops and launch a battle. Media specialists create a cultural diaspora of every war-related ethos from the Rambo figure to $\mathrm{BBC}$ broadcasts reaching the farthest regions of the globe. Propagandists the world over exchange information on how to make casualties palatable to noncombatants and human rights organizations. Everything from development dollars to human rights organizations, from covert operations specialists to illegal industries that gain from conflict, builds on the linkages of these networks that shape war and peace as we know it today.

Identifying those who are responsible does not mean that they will be held accountable for their role in the consequences. Impunity is built into the system, "an aspect of power ... embedded in the process of social differentiation [that] reinforces a highly unequal social order" (Gill 2004: 13). Formal state and international institutions of law have no chance against the mask of impunity. Unaccountability is strategic.

\section{The Accountability of War: What War Explains}

"Unaccountability was strategic," Nordstrom concludes as she looks back to the present time from 100 years in the future, a gripping reflection that opens this volume. With the benefit of hindsight, Nordstrom sees how profoundly modern war feeds-and feeds on-lethal inequalities, accelerates local and global economic crises, stimulates the institutionalization of extra-legal activities and organizations, and figures in the decline of the sovereign state with a concomitant rise of the 'para-state' and the 'extra-state'.

Nordstrom's look back is not speculation but evidence-based, unfolding each day, and documented in the daily newspaper- "history in the raw," Woolf ([1938] 1966: 7) calls it-and by others, including some anthropologists. In the presently developing situation, Nordstrom asserts, the state, a collection of linked institutions that provide people with core necessities, is a participant in its own undoing, withdrawing slowly but surely from its purportedly fundamental role. Gill 
explains the process for Colombia, tired mistress to the United States, where, to extend the metaphor, the domestic state is buttressed by the paramour whose interests are at odds with the greater part of the household. There are uprisings, but the official state apparatus cannot cope-its own rules are obstacles, its enforcers need a hand. Focused on containment and control, the state nurtures paramilitaries and sanctions the violation of law. There is no accountability, and organized crime has become institutionalized. The paramilitaries, Gill explains, "erected a mafia-like 'shadow-state"” and have "in effect become the state itself."

Variations of that domestic scene are patterned across the globe. As significant as the culturally specific differences may be at the level of the local, the fact is that each domestic war scene is tied to global systems that are themselves operating outside of law, regulation, and formal governments, even if colluding with them. In the global and political economy of war, the extraction of resources, the production of war-related and other goods, and the process of distribution are parasitic and opportunistic. Law is observed and state sovereignty respected only when they serve interests. Impunity and invisibility are strategic.

War has its own logic and creates its own outcomes. That war pays is an old saw. These days the profits are enormous, greater than anything war profiteers of old could have imagined. There are, of course, the huge defense contractors who proudly tout their strategic role in local or global warring, display their war weapons, ${ }^{2}$ or unabashedly showcase their products in international trade shows. ${ }^{3}$ As much as they display, they also hide the autocracy of corporate power (Kapferer 2005: 20), the multiple broken laws, the corruption, the bedfellows, the unsustainability, the destruction.

War drives decisions about the built environment and shapes the relationships of the people living and interacting within these spaces. In complex ways, war produces social identities (learn thy enemy), directs human activity (the work of war, subsistence in the context of war), and shapes social dynamics (more conflictual than cooperative), resulting in a greater likelihood of even more war. Ferguson notes, "Once a given society is internally adapted for war, making war becomes much easier-a necessity, even, for the reproduction of existing social relations." In a world internally adapted for it, war becomes ubiquitous.

It is in the context of this "unsure world" (Nordstrom) that ordinary people struggle for survival. In the face of dead bodies and ruined houses, they invent and scrounge, they construct and they take, they solve, persist, and endure. The violence of war, Nordstrom teaches us, becomes "institutionalized habit," encroaching on all the domains of social life and cutting across boundaries of the formal and informal, the legal and illegal, the global and local, the political and cultural.

When war ends and peace accords are signed, people who are its victims continue to suffer in the aftermath. There are predictable psychological effects of the trauma of war, including extreme anxiety, paralyzing flashbacks, and unbridled anger. The psychological wounds suffered by combatants and civilians often lead to more violence, as Bornstein and Manz point out in their poignant portraits of traumatized peoples. It is not uncommon that the victim becomes the victimizer, with brutality often being directed at those most near and dear. We know that war rips people apart, leaving the social fabric in shreds. Traditional 
activities of family and community life, work, and shared understandings are amputated, making it ever more difficult to escape the habitus of violence. War creates a "perverse transformation" (Manz) in which social life becomes marked by hostility and estrangement (rather than cooperation and collectivity), violence becomes normative, and weariness and resignation pervade daily life.

In places where overcoming the aftermath of war seems particularly difficult, where the violence is deeply entrenched and the social malaise especially potent, the obstacle is not cultural or social-psychological but rather structural. In these places, where the large-scale structures of domination and oppression remain firmly in place, the conditions that contribute to disaster, violence, and war have not been removed. The material inequalities and social inequities that explain war are still present despite the fact that there is no war-with battle lines drawn-to account for the violence. In these places, it is not just that 'peace' is uneasy and palpably fragile; it is that violence gets turned inward, resulting in domestic assaults, murder, lynching, and rape. These are symptoms of structural violence, although they appear as ordinary criminality, an illusion that places failure on individual or cultural weakness. Thus safely masked, the structures of power, domination, oppression, and inequality are not held accountable. Structural impunity renders it ever more difficult for 'damaged' people to rebuild a more peaceful society.

\section{Anthropology and Accountability}

I close this introduction by opening up for further discussion the responsibility of anthropology and individual anthropologists in facing up to the most significant crises of our times. In the prelude to this collection, Nordstrom leaves us no choice but to confront our discipline in its American manifestation and ourselves as professional anthropologists in the United States, considering the role of US imperial structures in warfare and global economic exploitation. Nordstrom grants us more power than we believe we have by alleging that what we do today does indeed configure our "emergent tomorrows."

It is safe to say that anthropologists in the United States do not see themselves as being influential enough to shape the course of future social conditions and events. Others see a kinship between US dominance in the world and American anthropology as a dominant power in the field of anthropology (Evens and Handelman 2005: 7) - they can imagine the possibility of such an influence. It is worthwhile for us to consider the possibilities. Perhaps it is pure self-aggrandizement to imagine that we have the power to shape the future. But if it is true, even to some degree, it would suggest that our rather constant claim to marginality is a myth. Buying into the myth of our own marginality is a safe retreat, serves to mask our privilege, and gets us off the hook. Our myths make us vulnerable to that which we refuse to recognize, and, in Nordstrom's words, make us complicit "with dangerous forms of hegemonic power."

Manz does not let us off the hook. She sees our privilege and our responsibility. In this world without borders, she claims, we must become global 
participants, not mere bystanders. "We have a far broader moral burden of accountability," declares Manz, who asserts that those in the United States "carry greater responsibility." Embedded as we are in the institutions of the state, our privilege is rooted in the current structures of power. For this reason, as Farmer demonstrates in word and deed, we need not question our moral duty as global participants. "Why that should be an embarrassment to academics is beyond me," Farmer (2006) remarked to an audience of anthropologists.

Not just any kind of global participation is appropriate. No matter the motivation, misguided actions that have lethal consequences are not forgivable. "I just can't stand to sit back and watch these mistakes happen over and over as people get killed, and do nothing," an anonymous anthropologist tells a reporter (Packer 2006: 66), thus defining her 'good' intentions in joining the Pentagon's Human Terrain System (HTS), a project established in 2006 at a purported cost of \$60 million (González 2008: 21). HTS, allegedly the brainchild of cultural anthropologist Montgomery McFate and social scientist David Kilcullen, is designed to apply anthropological methods to identify local cultural understandings, norms, motivations, and networks in the US counter-insurgency war effort in Afghanistan and Iraq. It is a wretched irony that we may look to endorsement by the US military to assure us that anthropology, in its methods and descriptive data, is not as marginal as we have come to believe.

Although the architects of HTS and its participants claim that their efforts are designed to "save lives" (González 2008: 21; Packer 2006: 66; Rohde 2007), activist anthropologists are systematically exposing the distortions behind those claims, revealing their role in "enabling the kill chain" (Vine 2007: B9; see also Wilcox 2007). While we might concede that understanding local dynamics could result in fewer deadly 'mistakes' on the killing ground (Vasquez), and even that it could bring resolution to disputes (Ferguson), to focus on this narrow truth blinds us to the larger story. As Reyna explains, the war violence in Afghanistan and Iraq perpetrated by the US reflects the political aspect of imperialism. "Empires are especially gory structures," Reyna reminds us. The kill chain is there, and anthropologists who participate in HTS are useful insofar as they are able to better identify the empire's opponents (see also González 2007: 16; Vogel 2007).

Anthropology, it seems, is not so much marginal as subject to selective attention by those outside the academy with power and influence. The history of the discipline is replete with examples of anthropology being central, not marginal, to social policy and action. As the HTS program illustrates, our data and our methods are viewed as precise, valid, authoritative, even useful, and certainly not threatening. It is these aspects of our discipline that are selected for attention.

This leaves theory as the aspect of our discipline selected for dismissal. Theory is nothing more that our explanation of what we see. It comprises that which we make visible by analysis. Theory is our interpretation of the data we collect on the ground, and our translation of the stories we hear in the field. It is what constitutes the greatest threat to those who would ignore us. Instead of leaving us discouraged or leading us to believe in our own marginality, we might draw strength from this knowledge. Seeing is power. 
I do not think Riall Nolan (2006) is correct: anthropology is not increasingly irrelevant to the big questions of the day, and not content to snipe from the sidelines as soon as it seems safe. There is an emerging movement of US anthropologists, affiliated with activist organizations and new groups ${ }^{4}$ as well as long-established organizations, ${ }^{5}$ who seem willing to hold our discipline accountable for our emergent tomorrows and are not afraid to report what they see. The contributors to this volume are among the growing number of anthropologists who are confronting war, leading the discussion on the most critical issues of contemporary society, and engaging actively in anti-imperial, anti-war efforts. In these pages, they analyze the arrogance of power; expose the defining attributes and logic of war, with its causes and consequences; and suggest what we might do to undermine the conditions that sustain and perpetuate it.

\section{Acknowledgments}

I am deeply indebted to the contributors to this issue, each of whom I consider intellectually and morally brave. I am grateful to Bruce Kapferer for his enthusiastic support of this important collection, to Berit Angelskår for her gracious assistance throughout the publishing process, to Shawn Kendrick for her sharp eye and careful editing, and to the Executive Program Committee of the American Anthropological Association for sponsoring the 2006 panel, "War," on which this collection is based. My deepest appreciation goes to Howard Horowitz for his help and inspiration. For their support and guidance, I also thank Maria D. Vesperi, Barbara Rylko-Bauer, Carolyn Nordstrom, Paul Farmer, Adrienne Waterston, Louise M. Waterston, Leah G. Horowitz, and Matthew Zuckerman.

\footnotetext{
Alisse Waterston is Professor of Anthropology, John Jay College of Criminal Justice, City University of New York. Her work focuses on the human consequences of structural and systemic violence and inequality. Publications include Love, Sorrow and Rage: Destitute Women in a Manhattan Residence (1999), "The Story of My Story: An Anthropology of Violence, Dispossession and Diaspora" (2005), and, with Antigona Kukaj, "Teaching Genocide in an Age of Genocides" (2007). She is the editor, with Maria D. Vesperi, of the forthcoming volume, Anthropology Off the Shelf: Anthropologists on Writing (Blackwell).
} 


\section{Notes}

1. Vasquez serves as president of the New York Chapter of Iraq Veterans Against the War and was a main organizer of "Winter Soldier Iraq and Afghanistan: Eye Witness Accounts of the Occupations" (http://www.ivaw.org/wintersoldier).

2. See, for example, the image gallery on Boeing's Web site (http://www.boeing.com/ companyoffices/ gallery/ids.html).

3. See, for example, IDEAS Pakistan. The tagline for the November 2008 show is "Weapons for Peace" (http://www.ideaspakistan.gov.pk/).

4. See, for example, http://concerned.anthropologists.googlepages.com/home.

5. An example is the AAA's Commission on the Engagement of Anthropology with the US Security and Intelligence Communities (http://dev.aaanet.org/cmtes/commissions/ CEAUSSIC/index.cfm).

\section{References}

AAA (American Anthropological Association). 2006. "Anthropologists Weigh in on Iraq, Torture at Annual Meeting." Press release. http://www.aaanet.org/pdf/iraqtorture.pdf (accessed 12 May 2008).

2007. "Anthropologists Oppose US Military Action Against Iran." Press release. http://www.aaanet.org/issues/press/upload/Advisory-Anthropologists-Oppose-US-MilitaryAction-in-Iran.pdf (accessed 12 May 2008).

Accardo, Gian Paulo. 2005. "Empire of Shame: A Conversation with Jean Ziegler." Counterpunch, 19 December. http://www.counterpunch.org/accardo12202005.html (accessed 14 November 2006).

Arendt, Hannah. [1963] 1992. Eichmann in Jerusalem: A Report on the Banality of Evil. New York: Penguin Classics.

1969. "A Special Supplement: Reflections on Violence." New York Review of Books. http://www.nybooks.com/articles/11395 (accessed 29 January 2008).

Berreman, Gerald D. 1968. "Is Anthropology Alive? Social Responsibility in Social Anthropology." Current Anthropology 9, no. 5: 391-396.

Blumenfeld, Laura. 2007. "Spurred by Gratitude, 'Bomb Lady’ Develops Better Weapons for U.S." Washington Post, 1 December.

Bornstein, Avram. 2002. Crossing the Green Line between the West Bank and Israel. Philadelphia: University of Pennsylvania Press.

Dewey, John. 1927. “Imperialism is Easy.” The New Republic 50, 23 March.

DOD (Department of Defense). 2007. Base Structure Report (Listing of Facilities) Fiscal Year 2007. Washington, DC: Office of the Deputy Under Secretary of Defense. http://www. defenselink.mil/pubs/BSR_2007_Baseline.pdf (accessed 28 January 2008).

Evens, T. M. S., and Don Handelman. 2005. "The Ethnographic Praxis of the Theory of Practice." Social Analysis 49, no. 3: 1-11.

Farmer, Paul. 2006. "A Physician Anthropologist Reflects on War and Public Health.” Paper presented at presidential panel, War. One hundred and fifth annual meeting of the American Anthropological Association.

n.d. “'Landmine Boy' and the Tomorrow of Violence." In Global Health in the Time of Violence, ed. Barbara Rylko-Bauer, Linda Whiteford, and Paul Farmer. Santa Fe, NM: School of Advance Research.

Ferguson, R. Brian. 1999. “A Paradigm for the Study of War and Society.” Pp. 389-437 in War and Society in the Ancient and Medieval Worlds: Asia, the Mediterranean, Europe, and Mesoamerica, ed. Kurt Raaflaub and Nathan Rosenstein. Cambridge, MA: Harvard University Press. 
Fried, Morton, Marvin Harris, and Robert Murphy, eds. 1967. War: The Anthropology of Armed Conflict and Aggression. New York: Doubleday \& Company.

Fussell, Paul. [1975] 2000. The Great War and Modern Memory. Oxford: Oxford University Press.

Gill, Lesley. 2000. Teetering on the Rim: Global Restructuring, Daily Life, and the Armed Retreat of the Bolivian State. New York: Columbia University Press. 2004. School of the Americas: Military Training and Political Violence in the Americas. Durham, NC: Duke University Press.

2007. "Anthropology Goes to War, Again." Focaal-European Journal of Anthropology 50: $139-145$.

Gjessing, Gutorm. 1968. "The Social Responsibility of the Social Scientist." Current Anthropology 9, no. 5: 397-402.

González, Roberto J. 2007. "Towards Mercenary Anthropology? The New US Army Counterinsurgency Manual FM 3-24 and the Military-Anthropology Complex." Anthropology Today 23, no. 3: 14-19.

2008. "Human Terrain: Past, Present and Future Applications." Anthropology Today 24, no. 1: 21-26.

Gough, Kathleen. 1968. "New Proposal for Anthropologists." Current Anthropology 9, no. 5: 403-435.

Hastrup, Kirsten, Peter Elsass, Ralph Grillo, Per Mathiesen, and Robert Paine. 1990. "Anthropological Advocacy: A Contradiction in Terms?" Current Anthropology 31, no. 3: 301-311.

Hobbes, Thomas. 1964. Leviathan. New York: Washington Square Press.

Holland, Dorothy, Donald M. Nonini, Catherine Lutz, Lesley Bartlett, Marla FrederickMcGlathery, Thaddeus C. Guldbrandsen, and Enrique G. Murillo, Jr. 2007. Local Democracy Under Siege: Activism, Public Interests and Private Politics. New York: NYU Press.

Jones, Delmos J. 1971. "Social Responsibility and the Belief in Basic Research: An Example from Thailand." Current Anthropology 12, no. 3: 347-350.

Kapferer, Bruce, ed. 2004. State, Sovereignty, War: Civil Violence in Emerging Global Realities. New York: Berghahn Books. ed. 2005. Oligarchs and Oligopolies: New Formations of Global Power. New York: Berghahn Books.

Khanna, Parag. 2008. "Waving Goodbye to Hegemony.” New York Times Magazine, 27 January.

Manz, Beatriz. 1988. Refugees of a Hidden War: The Aftermath of Counterinsurgency in Guatemala. Albany: SUNY Press.

2004. Paradise in Ashes: A Guatemalan Journey of Courage, Terror and Hope. Berkeley: University of California Press.

Nolan, Riall W. 2006. “Torture and Social Scientists.” Posted comment, 22 November. http:// www.insidehighered.com/news/2006/11/22/anthro (accessed 20 December 2006).

Nordstrom, Carolyn. 1997. A Different Kind of War Story. Philadelphia: University of Pennsylvania Press.

2007. Global Outlaws: Crime, Money, and Power in the Contemporary World. Berkeley: University of California Press.

Ortega, Ramona. 2006. "Co-Defenders: How Human Rights Activists and Anthropologists Can Work Together." North American Dialogue 9, no. 2: 5-8.

Packer, George. 2006. "Knowing the Enemy: The Anthropology of Insurgency." New Yorker, 18 December, 60-69.

Price, David H. 2004. Threatening Anthropology: McCarthyism and the FBI's Surveillance of Activist Anthropologists. Durham, NC: Duke University Press.

Remarque, Erich Maria. [1929] 1982. All Quiet on the Western Front. New York: Random House. Rohde, David. 2007. "Army Enlists Anthropology in War Zones." New York Times, 5 October. Rylko-Bauer, Barbara. 2007. "Introductory Remarks: Global Health in the Time of Violence." Paper presented at plenary session on Global Health in the Time of Violence. Sixty-seventh annual meeting of the Society for Applied Anthropology. 
2008. "Applied Anthropology and Counterinsurgency." Newsletter: Society for Applied Anthropology 19, no. 1: 1-5.

Rylko-Bauer, Barbara, Merrill Singer, and John Van Willigen. 2006. "Reclaiming Applied Anthropology: Its Past, Present, and Future." American Anthropologist 108, no. 1: 178-190.

Sanford, Victoria, and Asale Angel-Ajani, eds. 2006. Engaged Observer: Anthropology, Advocacy, and Activism. Rutgers, NJ: Rutgers University Press.

Saramago, José. 1998. Blindness. New York: Harcourt Brace \& Company.

Shaw, Martin. 2000. "The Contemporary Mode of Warfare? Mary Kaldor's Theory of New Wars." Review of International Political Economy 7, no. 1: 171-180.

Singer, Merrill. 1990. "Another Perspective on Advocacy." Current Anthropology 31, no. 5: 548-550.

Tickner, J. Ann. 2001. Gendering World Politics: Issues and Approaches in the Post-Cold War. New York: Columbia University Press.

Trumbo, Dalton. [1939] 1989. Johnny Got His Gun. New York: Bantam Books.

Vine, David. 2007. "Enabling the Kill Chain.” Chronicle of Higher Education, 30 November.

Vogel, Richard D. 2007. "Mapping the Human Terrain and Developing Kill Chains: Social Science in Service to Capitalism." Monthly Review Webzine, 11 June. http://www. monthlyreview.org/mrzine/vogel061107.html (accessed 12 February 2008).

Vonnegut, Kurt. [1969] 1991. Slaughterhouse-Five. New York: Dell Publishing.

Wilcox, John. 2007. "Precision Engagement-Strategic Context for the Long War: Weapons Technology Blueprint for the Future.” 1 February. http://concerned.anthropologists. googlepages.com/WilcoxKillChain.pdf (accessed 12 February 2008).

Wolf, Eric R., and Joseph G. Jorgensen. 1970. "Anthropology on the Warpath in Thailand.” New York Review of Books, 19 November.

Woolf, Virginia. [1938] 1966. Three Guineas. New York: Harcourt Brace \& Company.

Zinn, Howard. 2001. On War. New York: Seven Stories Press. 